\title{
Changes of Accounting Firm Organizational Form, Accounting Firm Size and Audit Quality
}

\author{
$1, a$ Zhang Xuehua \\ ${ }^{1}$ School of economics and management, Southwest Jiao Tong University, Chengdu, Sichuan \\ 610000, China \\ azhangxuehua0601@163.com
}

Keywords: Accounting firm Organizational from Audit quality.

Abstract. This paper, for the first time, makes an investigation into the impact of the dynamic changes in organizational forms of accounting firms on the result of audit, and the findings indicate that auditor will be more prudent to issue audit opinion, and therefore, its quality sees a considerable improvement, whose level of impact is obviously lower than that of non-Big 10" group.

\section{Introduction}

Audit quality serves as the core of the research on audit theory and the most research in the field of audit directly or indirectly focuses on the audit quality, but by now, many an issue is till outstanding, including the influencing mechanism of accounting firm's change of organizational form on the audit quality. This paper, in a longitudinal way, makes an analysis of the difference in the audit opinion resulted from the dynamic change of organizational form of accounting firm, and then, we figure out the influence on audit quality and provide experimental evidence to the effect of implementing the restructuring of China's accounting firm; expound the mechanism of the impact stemmed from the changes in organizational forms of the accounting firms of all sizes on the audit quality.

\section{Literature review and the arising of the question of assumption for research}

Literature review:Yuan Hongqi and Li Haijian (2003) are first involved in the documents of empirical study on organizational form of accounting firm in China. Their findings indicate that the firms of various sizes have taken the features of clients' companies in financial risk into account, and therefore, their forms will be no of outstanding influence on the audit opinion. Firth, Mo and Wong

(2012) also make research on the forms of the firms in China and find that, compared with the accounting firm of limited company, the common firm of partnership enjoy higher probability in issuing non-standard opinion and the opinion about sustained operation, so the manipulable accrue is even smaller.

Arising problem for research:This paper, from the perspective of audit opinion, the first outcome of audit findings, inspects the impact of the change of accounting firm on the audit quality. This paper adopts the approach of empirical study to test the influence of the change in question on the decision of audit opinion, and probe into the impact of the change of the firm from the angle of audit opinion, the detailed research covers: 1.whether auditors become more prudent to issue audit opinion and the audit quality gets improved after the conclusion of the change in the organizational form; 2 . Whether the influencing mechanisms on the issue of audit opinions of the firms in "Big 10" and "non-Big 10" are different.

\section{The design of research}

The selection of sample and date source:This papers takes the listed companies of A Share in both Shanghai Stock Exchange and Shenzhen Stock Exchange from 2008 to 2013 as the research sample and finally get observation results of 5494 samples. We process all the continuous variables at the levels of 1 percent and 99 percent through winsorize so as to offset the impact of extreme value on the 
research result. All the data adopted in this paper is from the database of RESSET or obtained from the links provided by it.

Basic model:This paper utilizes regression model of Probit to test the relations among the change and size of the organizational form and audit opinion, and we design the below basic regression model so as to complete the basic test of assumption:

$$
\begin{gathered}
\mathrm{OP}=\beta_{0}+\beta_{1} \mathrm{PACT}+\beta_{2} \mathrm{TA}+\beta_{3} \mathrm{ROE}+\beta_{4} \mathrm{CURRT}+\beta_{5} \mathrm{DBEQURT}+\beta_{6} \mathrm{AR}+\beta_{7} \mathrm{INV}+\beta_{2} \mathrm{NCROE} \\
\quad+\varepsilon \\
\begin{array}{c}
\mathrm{OP}=\beta_{0}+\beta_{1} \mathrm{PACT}+\beta_{2} \mathrm{BIG} 10+\beta_{3} \mathrm{PACT} * \mathrm{BIG} 10+\beta_{4} \mathrm{TA}+\beta_{5} \mathrm{ROE}+\beta_{6} \mathrm{CURRT} \\
+\beta_{7} \mathrm{DBEQURT}+\beta_{2} \mathrm{AR}+\beta_{9} \mathrm{INV}+\beta_{10} \mathrm{NCROE}+\varepsilon
\end{array}
\end{gathered}
$$

Model 1 is employed to test the impact of the change of the organizational form of accounting firm on the audit opinion. OP is virtual variable, which stands for audit opinion, when it is non-standard opinion, $\mathrm{OP}$ is 1 and it is 0 under other situations. The non-standard opinions consist of: non-reservation and memo, reservation, negative opinion and failure to comment. PACT means the change of organizational form of accounting form and after the change, PACT is 1 and it is 0 under other situations. Model 1 is designed to test the coefficient of PACT and it is outstandingly positive, which means, under the circumstance that other conditions remain unchanged, auditors are likely to issue non-standard comments, after the change in organizational forms, and become more prudent and get the quality of audit improved.

Model 2 is used to test whether the impact of the change on the decisions of audit opinions of domestic "Big 10" and "non-Big 10" is different. When the accounting firm is in the "Big 10", Big is 11 , while it is 0 under other situations. PACT*BIG10 is the interactive item of PACT and Bing10, and the definitions and models of other variables are same. In model 2, the coefficient we need to investigate is $\cdots$, and if it is outstanding, it means the impact of the change of the organizational form

\begin{tabular}{|c|c|c|}
\hline Name & Symbol & Definition \\
\hline Audit opinion & OP & When audit opinion is non-standard, it is 1 , or it is 0 \\
\hline $\begin{array}{l}\text { Change in of } \\
\text { organizational } \\
\text { form of } \\
\text { accounting firm }\end{array}$ & PACT & $\begin{array}{l}\text { When the accounting firm sees changes in its } \\
\text { organizational form, it is } 1 \text {, or it is } 0\end{array}$ \\
\hline $\begin{array}{l}\text { Size } 1 \text { of } \\
\text { accounting firm }\end{array}$ & BIG10 & $\begin{array}{l}\text { In accordance with the ranking in the comment, "Big } \\
10 " \text { is } 1 \text {, or it is } 0\end{array}$ \\
\hline $\begin{array}{l}\text { Size } 2 \text { of } \\
\text { accounting firm }\end{array}$ & BIGTQ10 & $\begin{array}{l}\text { According to the ranking in the all auditing firms, "Big } \\
10 " \text { is } 1 \text {, or it is } 0 .\end{array}$ \\
\hline $\begin{array}{l}\text { Size } 3 \text { of } \\
\text { accounting firm }\end{array}$ & BIGTA10 & $\begin{array}{l}\text { As per the ranking of the asset of auditing firm, "Big } \\
10 " \text { is } 1 \text {, or it is } 0 \text {. }\end{array}$ \\
\hline Size of asset & TA & Natural logarithm of total asset \\
\hline Return on equity & ROE & The percentage of net profits and net asset \\
\hline Current ratio & CURRT & The ratio of current assets and current liabilities \\
\hline Equity ratio & $\begin{array}{l}\text { DBEQU } \\
\text { RT }\end{array}$ & The ratio of total indebtedness and total owner's equity \\
\hline Accrued items 1 & AR & $\begin{array}{l}\text { Surplus management of virtual company ratio of } \\
\text { accounts receivable and the income of main business }\end{array}$ \\
\hline Accrued items 2 & TNV & $\begin{array}{l}\text { Surplus management of virtual company - ratio of } \\
\text { stock and main business }\end{array}$ \\
\hline $\begin{array}{l}\text { Return on equity } \\
\text { of non-main } \\
\text { business }\end{array}$ & NCROE & $\begin{array}{l}\text { Profit Margin on Net Assets reduces the ROE of main } \\
\text { business }\end{array}$ \\
\hline
\end{tabular}
on the "Big 10" of large accounting firms and on the "non-Big 10" of small ones is different. The names, symbols and definitions of variables are showed in the below table.

Table 1 the definitions and explanations of variables 
Descriptive statistics and relativity analysis:Table 2 is mainly about the descriptive statistics and relativity analysis of relevant variables. From the table, we can see the average value of OP, PACT and BIG10 is separately $0.0562,0.2599$ and 0.4769 , while the standard deviation of them is 0.2304 , 0.4386 and 0.4995 . From the table, we can see the average value T, PACT and OP have outstanding positive correlation at the level of $10 \%$, BIG10 and OP have outstanding positive correlation at the level of 5\% while BIG and PACT have also outstanding positive correlation at the level of $5 \%$. The data in the table shows that the accounting firm, after the change in its organizational form, is more likely to issue non-standard audit opinion and the audit quality will get improved; the accounting firms in "Big 10" will get improved in audit quality after its change in organizational form.

Table 2 Descriptive statistics and relativity analysis of major variables

\begin{tabular}{|c|c|c|c|c|c|}
\hline \multicolumn{6}{|l|}{ Table 2-1 } \\
\hline $\begin{array}{l}\text { Symbol of } \\
\text { variable }\end{array}$ & $\begin{array}{l}\text { The number } \\
\text { of the } \\
\text { variable } \\
\text { under } \\
\text { observation }\end{array}$ & $\begin{array}{l}\text { Average } \\
\text { value }\end{array}$ & $\begin{array}{l}\text { Maximum } \\
\text { value }\end{array}$ & $\begin{array}{l}\text { Minimum } \\
\text { value }\end{array}$ & $\begin{array}{l}\text { standard } \\
\text { deviation }\end{array}$ \\
\hline $\mathrm{OP}$ & 5494 & 0.0562 & 1 & 0 & 0.2304 \\
\hline PACT & 5494 & 0.2599 & 1 & 0 & 0.4386 \\
\hline BIG10 & 5494 & 0.4769 & 1 & 0 & 0.4995 \\
\hline \multicolumn{6}{|l|}{ Table 2-2 } \\
\hline $\begin{array}{l}\text { Symbol of } \\
\text { variable }\end{array}$ & $\mathrm{OP}$ & PACT & BIG10 & BIGTQ10 & BIGTA10 \\
\hline $\mathrm{OP}$ & 1.000 & & & & \\
\hline PACT & $0.023^{*}$ & 1.000 & & & \\
\hline BIG10 & $0.034^{* *}$ & $0.226 * *$ & 1.000 & & \\
\hline
\end{tabular}

\section{Experimental evidence}

What we can learn from the result of regression in model 1 that PACT and OP have outstanding positive correlation, which indicates the accounting firm sees the improvement in its audit quality after the change in its organizational form. From the result of regression in model 2, we can see PACT and OP have outstanding positive correlation at the level of $1 \%$, which shows that the accounting firms of different sizes will see the increase in issuing audit opinion and improvement in audit quality after the change in question; BIG10 and OP have outstanding positive correlation at the level of $1 \%$., which means that the accounting firms in "Big10" will tend to issue non-standard audit opinion and get improved in audit quality.

We divide all the sample accounting firms into two groups, namely, "Big 10" auditing group and "non Big 10"group, and the result of regression model we get in the next step are shown as (3) and (4) in Table 3. From the table, we can clearly see that PACT and OP have no outstanding correlation in the first group, while in the latter group, they have outstanding positive correlation at the outstanding level.

\section{Conclusions of research}

This paper probes into the influencing mechanism of the change in the organizational form of accounting firm on its audit quality. The conclusions of research show: 1 . after the accounting firm experiences the change in its organizational form, auditors will be more prudent to issue audit opinion, tend to issue the non-standard audit opinion and the audit quality get improved; 2 . the change in question will affect the issue of audit opinion for the "Big 10" or "non-Big ten" firms of various sizes in obviously distinct ways and the impact of the change on the audit quality of the "Big10" firms is significantly less than that of "non-top 10" ones. 
The contribution of paper lies in that, for the first time, it makes an investigation into the impact of the dynamic change in the organizational form on its audit quality, fills in a gap of current empirical study and helps the supervisory authorities of governments with further knowledge of the effect in policy brought by the changes in question as well as provide theory evidence and experience support so that the authorities can formulate the later relevant policies. So the research in this paper also has some connotation in policy.

Table 3 Probit result of regression

\begin{tabular}{|c|c|c|c|c|}
\hline & (1) & (2) & (3) & (4) \\
\hline & OP & OP & OP & $\mathrm{OP}$ \\
\hline _CONS & $\begin{array}{l}4.638 * * * \\
(6.52)\end{array}$ & $\begin{array}{l}4.632 * * * \\
(6.37)\end{array}$ & $\begin{array}{l}5.661 * * * \\
(5.98)\end{array}$ & $\begin{array}{l}3.843 * * * \\
(4.04)\end{array}$ \\
\hline PACT & $\begin{array}{l}0.430 * * * \\
(4.76)\end{array}$ & $\begin{array}{l}0.942 * * * \\
(5.97)\end{array}$ & $\begin{array}{l}0.136 \\
(1.16)\end{array}$ & $\begin{array}{l}0.951 * * * \\
(5.86)\end{array}$ \\
\hline BIG10 & & $\begin{array}{l}0.341 * * * \\
(3.68)\end{array}$ & & \\
\hline PACT*BIG10 & & $\begin{array}{l}-0.815^{* * *} \\
(-4.28)\end{array}$ & & \\
\hline TA & $\begin{array}{l}-0.701^{* * *} \\
(-9.62)\end{array}$ & $\begin{array}{l}-0.718^{* * *} \\
(-9.51)\end{array}$ & $\begin{array}{l}-0.798 * * * \\
(-7.80)\end{array}$ & $\begin{array}{l}-0.630 * * * \\
(-6.11)\end{array}$ \\
\hline ROE & $\begin{array}{l}0.00285 \\
(0.48)\end{array}$ & $\begin{array}{l}0.00347 \\
(0.58)\end{array}$ & $\begin{array}{l}-0.450 * * * \\
(-3.89)\end{array}$ & $\begin{array}{l}0.00766 \\
(0.68)\end{array}$ \\
\hline CURRT & $\begin{array}{l}-0.0677^{*} \\
(-1.89)\end{array}$ & $\begin{array}{l}-0.0704 * \\
(-1.94)\end{array}$ & $\begin{array}{l}-0.0719 * * * \\
(-3.70)\end{array}$ & $\begin{array}{l}-0.0588^{* *} \\
(-2.48)\end{array}$ \\
\hline DBEQURT & $\begin{array}{l}0.000267 * * * \\
(3.68)\end{array}$ & $(-1.94)$ & $\begin{array}{l}0.000296 * * * \\
(3.03)\end{array}$ & $\begin{array}{l}0.000168 * \\
(1.84)\end{array}$ \\
\hline $\mathrm{AR}$ & $\begin{array}{l}-0.498^{*} \\
(-9.62)\end{array}$ & $\begin{array}{l}-0.487^{*} \\
(-1.66)\end{array}$ & $\begin{array}{l}-0.270 \\
(-1.04)\end{array}$ & $\begin{array}{l}-0.777 * * \\
(-2.16)\end{array}$ \\
\hline INV & $\begin{array}{l}0.00820 * * \\
(2.22)\end{array}$ & $\begin{array}{l}0.00795 * * \\
(2.11)\end{array}$ & $\begin{array}{l}0.00188 \\
(0.40)\end{array}$ & $\begin{array}{l}0.0334^{* * *} \\
(3.66)\end{array}$ \\
\hline NCROE & $\begin{array}{l}-0.00484 \\
(-0.80)\end{array}$ & $\begin{array}{l}-0.00544 \\
(-0.89)\end{array}$ & $\begin{array}{l}0.451^{* * *} \\
(3.88)\end{array}$ & $\begin{array}{l}-0.0119 \\
(-1.05)\end{array}$ \\
\hline $\mathrm{N}$ & 5494 & 5494 & 2641 & 2853 \\
\hline PseudoR2 & 0.1551 & 0.1707 & 0.1827 & 0.2188 \\
\hline
\end{tabular}

Note: $* * *, * *$ and $*$ means the outstanding at the outstanding levels of $1 \%, 5 \%$ and $10 \%$ separately.

\section{References}

Chai fa. Thinking on the Perfection of the Organizational Form of Accounting Firm in China, 2003,

(9) : $9-13$

Chen ying. Organizational Form of Accounting Firm in the USA, the Chinese Certified Public Accountant, 2004, (10) : 60-62

Chu Yihong, Luo Huaijing. On the Reasons of the Low Quality of Practice for Certified Public Accountant and Its Countermeasures, 2000, (5) : 25-26

Blay,A. Independence threats, litigation risk, and the auditor's decision process. Contemporary Accounting Research, 2005, 22(4):759-789

Burton,F.G.,T.J.Wilks andM.F.Zimbelman. The impact of audit penalty distributions on the detection and frequency of fraudulent reporting. Review of Accounting Studies, 2011, 16(4):843-865

Chan,D.K. and K.Wong. Scope of auditors'liability, audit quality, and capital investment. Review of Accounting Studies, 2002, 7(1):97-122

Choi,J. and T.J.Wong. Auditors'governance functions and legal environments: An international investigation. Contemporary Accounting Research, 2007, 24(1):13-46 
Choi,J., J.Kim, X.Liu and D. Simunic. Audit pricing, legal liability regimes, and big 4 premiums: Theory and cross-country evidence. Contemporary Accounting Research, 2008, 25(1):55-99

DeAngelo, L. Auditor size and audit quality. Journal of Accounting and Economics, 1981, 3:189-199 Firth,M., P.L.L.MO and R.M.K.Wong. Auditor's organizational form, legal liability, and reporting conservatism: Evidence from China. Comtemporary Accounting Research, 2012, Forthcoming Hope,O. and J.C.Langli. Auditor independence in a private firm and low litigation risk setting. The Accounting Review, 2010, 85(2):573-605

Khurana,I.K. and K.K.Raman. Litigation risk and the financial reporting credibility of big 4 versus non-big 4 audits: Evidence from anglo-American countries. The Accounting Reivew, 2004, 79(2):473-495

King,R.R. and R.Schwartz. Legal penalties and audit quality: An experimental investigation. Contemporary Accounting Research, 1999, 16(4):685-710

Laux,V. and D.P.Newman. Auditor liability and client acceptance decisions. The Accounting Review, 2010, 85(1):261-285

Liu,C. and T.Wang. Auditor liability and business investment. Contemporary Accounting Research, 2006, 23(4)1051-1071

Muzatko, S. R., K. M. Johnstone, B. W. Mayhew, and L. E. Rittenberg.An empirical investigation of IPO underpricing and the change to the LLP organization of audit firms. Auditing: A Journal of Practice \& Theory, 2004, 23:53-67

Pae,S. and S. Yoo. Strategic interaction in auditing: An analysis of auditors'legal liability, internal control system quality, and audit effort. The Accounting Review, 2001, 76(3):333-356

Seetharaman,A., F.A.Gul and S.G.Lynn. Litigation risk and audit fees: Evidence from UK firms cross-listed on US markets. Journal of Accounting and Economics, 2002, 33(1):91-115

Shu,S.Z. Auditor resignations: clientele effects and legal liability. Journal of Accounting and Economics, 2000, 29(2):173-205

Schwartz,R. Legal regimes, audit quality and investment. The Accounting Review, 1997, 72(3):385-406

Smith,J.L. Investors'perceptions of audit quality: Effects of regulatory change. Auditing: A Journal of Practice \& Theory, 2012, 31(1):17-38

Yu,H. Legal systems and auditor independence. Review of Accounting Studies, 2011, 16(2):377-411 